\title{
Academic Freedom In These Times: Three Lessons From York University
}

\author{
Penni Stewart \\ York University \\ pstewart@yorku.ca
}

Dedicated to the memory of Professor David Noble (1945-2010), longtime advocate for social justice, champion of academic freedom, and tireless critic of corporatism, authoritarianism, and repression in his own and all universities

\begin{abstract}
Academic freedom faces formidable challenges in the current political and social climate, from external political forces as well as state pressures reshaping the university in the corporateimage. Three recent events at York University in Toronto relating to Palestine/Israel conflict demonstrate the fragility of academic freedom and freedom of expression. As the university is transformed by a competitive, corporate mentality, administrators concerned with their public image become more vulnerable to intimidation from the outside, in these cases pro Israel groups. Campus dissent is suppressed under the guise of seeking restraint. In these times academic staff must come forward to defend academic freedom.
\end{abstract}

Keywords: Academic freedom, York University, corporate university.

\section{Academic Freedom in These Times: Three Lessons From York University}

In November 2004 Professor David Noble, a York University professor, set off a storm at York University when he distributed a flier arguing that pro-Israel interests in the leadership of the York University Foundation were influencing University decisions. As at many institutions, the Foundation is a separate, non-profit fundraising arm of the University. Six years later the reverberations within and beyond York continue to frame contemporary academic culture and raise fears for the long-term health of academic freedom and freedom of expression.

The "Noble case" is the first of three instances of public controversy and their impact on academic freedom that I discuss here. A student-led rally on the Israeli and Palestine conflict is the second, and the third case, most recent and most public, is the "Mapping" conference held in June 2009. Together, these events raise questions about the critical forces at work in our universities that undermine academic freedom and the democratic and collegial culture that is its institutional bedrock.

Academic freedom rests on the idea that knowledge creation can only take place where academics are free to teach, conduct research, and disseminate results without fear of retribution. 
The scope of academic freedom is far reaching, providing the scholar with the right to voice opinions on issues beyond his or her narrow professional expertise. Academic freedom as a professional right is linked to, but analytically distinct from freedom of expression, an inherent right of individuals. Academic freedom and freedom of expression are today in grave danger of curtailment, from what Jonathan Cole (2005) describes "as a rising tide of anti-intellectualism" (p. 5), and from what Richard Falk (2007) sees as part of a "multidimensional campaign against genuine democracy" (p. 369). The ascendancy of entrepreneurial university managements who emphasize a market-based rationality in which education becomes a consumer good, and who have a correspondingly anxious eye on consumer satisfaction and public relations as well as governments concerned with fiscal constraints, corporate ties and short term priorities, are paving the way for dangerous widespread institutional change. More alarming is the extent to which political pressure by external advocacy groups is reshaping the academic landscape. Below I begin with a brief description of each event.

Professor Noble's saga began with his distribution of an unsigned flier on Thursday, November 18, 2004, to students in his classes and at a film screening, titled "The York University Foundation: The Tail that Wags the Dog (Suggestions for Further Research)" (Goodfellow, Arbitration Award, 2007. p. 2). From that flier, the nub of Professor Noble's argument is:

(1) The York University Foundation (YUF), which was established in 2002, is the tail that wags the dog that is York University (YU). The administration of YU, like every other University, is guided foremost by fundraising considerations. York's fundraising affairs are directed by Paul Marcus, who runs both YUF and the York Development Office. Contributions to YU now come through YUF. Both the YU Chair of the Board of Governors, Marshall Cohen and the YU President, Lorna Marsden, sit also on the YUF Board. The YUF has a staff of 34 people.

(2) The YUF is biased by the presence and influence of staunch pro-Israel lobbyists, activists, and fundraising agencies.

(3) The recent decisions by the YU President and Board of Governors to discipline proPalestinian activists ... And otherwise to clamp down on campus protests, appear to reflect the strongly pro-Israel orientation of the YUF.

Other examples of pro-Israel orientation followed, as did a list of the YUF Board of Directors and their connections to Israel.

The next day, York University, the York University Foundation, and two student groups - Solidarity for Palestinian Human Rights (SPHR) and Hillel at York-jointly issued a press release sent to major news organizations across the country:

York University strongly condemns this highly offensive material, which singles out certain members of the York community on the basis of their ethnicity and alleged political views, including philanthropic volunteers who serve on the board of the York University Foundation," said Lorna Marsden, York University President and ViceChancellor. "These views must not be permitted to diminish a culture of mutual respect 
on our campus and which unites us as a community. (Goodfellow, Arbitration Award, 2007, p. 1)

On the same day, the Canadian Jewish Congress (CJC) also released a media statement naming the author as Professor Noble:

"David Noble's actions are appalling," said CJCONT Chair Joel Richier. "This is anti-Semitism, vaguely disguised as anti-Israel rhetoric. It's the same kind of pernicious action that has historically been used to attack Jews and their involvement in wider society," he added. (Goodfellow, Arbitration Award, 2007, p. 5)

By Saturday, Canadian media began to follow up on the story. As the media stories multiplied, Professor Noble expressed his outrage at being labeled "an anti-Semite by his own University" and demanded an apology.

About a week later, the York University Faculty Association (YUFA) filed a grievance claiming, among other things, that the York University administration had violated Professor Noble's academic freedom when they issued the press release. The grievance argued ". . . the Administration libeled and branded the griever as anti-Semitic", and had

either deliberately or negligently misrepresented the nature of the issues raised in the flyer and the criticisms and comments that Professor Noble made in the flyer regarding the relationship between the York University Foundation and recent decisions by the York University President and the Board of Governors.

(York University Faculty Association, 2007, p.5)

After three years and seventeen days of arbitration, Arbitrator Russell Goodfellow agreed with YUFA, finding that the York administration had breached Professor Noble's academic freedom. Goodfellow stated ". . . it is clear that York failed to live up to the obligations imposed by the Article" (Article 10.01 of the Collective Agreement). "The implied accusations of racism and bigotry, and the implicit suggestion that no students should be exposed to the kind of material which Professor Noble had produced, were a clear violation of his academic freedom" (Goodfellow, Arbitration Award, 2007, p. 30).

More emphatically:

Having said that, the fact remains, as detailed in the first part of this award, that York breached Article 10.01 of the Collective Agreement by failing to respect Professor Noble's rights as an academic. Indeed, it may be said that York failed to extend Professor Noble even the most basic of courtesies that might reasonably be expected to be enjoyed by a faculty member. The University publically vilified his work without first contacting him or YUFA to advise of its concerns, to investigate the matter, or to indicate what it was contemplating. Had it done so, it is at least possible that much, if not all, of what ensued could have been avoided. And, lest there be any doubt on the point, I do not view Professor Noble and York University as standing in the same position in respect of their actions. Professor 
Noble handed out a two-page flyer to a number of people on campus, at least in part a scholarly exercise and in accordance with his Collective Agreement rights. York, by contrast, issued a two-page Media Release to several of the major news organizations in the country and posted it on its web-site for the world to see. While Professor Noble, as I have already stated, might reasonably have expected such treatment from others, he had the right to expect more from York.

(Goodfellow, Arbitration Award, 2007, p. 54)

The public and institutional attack on David Noble follows precisely the trajectory described by Cole (2005) in other highly publicized cases like that of Professor Joseph Massad of Columbia University who became a victim of a smear campaign accusing him of anti-Semitism (see also Brand, 2007). Having been summarily accused of racism and bigotry, Professor Noble very quickly faced a barrage of mainly misleading media reports that raised a public alarm further fed by the University's denunciation, in this case the media release. Although in the end, the attack on Noble failed, we shouldn't conclude that harm wasn't done. In the more than three years that it took to resolve the situation, Noble's personal and professional reputation was under assault. Arbitrations tend to be distressingly slow in part because employers seek every avenue of delay; understanding that delay overwhelmingly favours those in power. In Noble's case there were five interim decisions for various reasons (for an example see York University Faculty Association, 2005). By the time a final decision is rendered public, attention has moved on and the individual griever is left with at best, the cold comfort of having been exonerated. There is social damage as well. The public campaign accusing Noble of antiSemitism served notice to others in the academic community that they ought to be very careful about transgressing boundaries to avoid sharing the same discrediting fate. Cole (2005) argues that the lesson is to understand these attacks in the broader context of a struggle over power and control. He writes: "Critics of the university ... tend to blur the distinction between speech and action. They accuse professors of inappropriate action and intimidation when they are actually trying to attack the content of their ideas" (p. 8). Here, the campaign against Noble very effectively used the smokescreen of antiSemitism to entirely shift the argument away from Noble's academic argument that there was an organized pro-Israel lobby involved with the York University Foundation. This idea became the unmentionable.

The Noble case exemplifies the fragility of academic freedom once it is out of the classroom. Rather than being " $a$ central, arguably the central value of university life ... something to be protected all the time, everywhere" as Past York President Harry Arthurs put it, David Noble's academic freedom wasn't even considered as relevant to an administration in a rush to defend their public image (Arthurs, 1995, p. 1). And as my next examples will show, although academic freedom continues to be vaunted as singularly important, in practice, there is little patience with the idea that the pursuit and protection of academic freedom should almost always trump constraint. Instead, the emphasis of today's administrators-whether university or governmental has shifted from protection of academic freedom to the responsibilities that accompany the freedom. 
My second example is a stark description of the growing influence and hyper vigilance of external advocacy groups, in this case, groups concerned with anti-Semitism and advocating for Israel. My concern here is how external pressure, through organized campaigns designed to mobilize the public, constrains freedom of expression for students and academic staff.

In 2008, Toronto Life, a mainly "lifestyle" local monthly magazine, featured an article on "York's Middle East War," which began with the provocative statement that "the Israel-Palestine conflict is poisoning York University with violent demonstrations, riot cops on campus, lawsuits, even a Human Rights Commission inquiry" (Grainger, 2008). The writer went on to raise the question of whether newly appointed President Mamdouh Shoukri "stood a chance" of bringing peace to the campus.

On February $11^{\text {th }} 2009$, a press conference, ostensibly over a petition to recall the student government because of its support for a recent strike by contract academic staff, resulted in a confrontation between pro-Israeli and pro-Palestinian students. Accusations of anti-Semitism were leveled at some pro-Palestinian students, which they vehemently denied, though they had chanted "racists off campus" at one point. The next day a rally by Students Against Israeli Apartheid (SAIA) drew a large group of pro-Israeli students. A prolonged shouting match between the two groups ensued (Yfile, 2009a).

More remarkable than the actual events, was the hyperbolic reaction of external advocacy groups, who used them to attack Israel Apartheid Week, planned for March. Three days after the press conference, on February $14^{\text {th }}$, the National Post newspaper carried a full-page ad by B'nai Brith Canada headlined, "Stop the Hate Fests on Canadian University Campuses." It called on university presidents, boards of governors, professors, alumni, and benefactors to step up to prevent Israeli Apartheid Week and stop the "daily, ongoing, anti-Jewish agitation that has taken root on campuses across the country" (B'nai Brith, 2009a). The ad was followed by a public "call to action" recognizing that "the anti-Semitism that masquerades as anti-Israel propaganda is the new threat" (B'nai Brith, 2009b). The perpetually money-losing National Post was founded by Conrad Black to provide a right wing, national alternative to the Canadian newspaper of record, the Toronto Globe and Mail.

Two weeks later, on February $24^{\text {th }}$, B'nai Brith Canada called on the Canadian Association of Chiefs of Police to be "on high alert" citing "inadequate policing of university campuses which have become breeding grounds for promoting hatred against Jewish students" (B'nai Brith, 2009c). The same day, leaders of the student groups who had participated in the February $12^{\text {th }}$ rally, were officially warned, by the Office of the Vice-President Students, that sanctions were imminent, pending receipt of written appeals from the organizations (H. Farah, personal communication, February 24, 2009).

On February $26^{\text {th }}$, officials of B'nai Brith Canada met with the York president and, according to their press release, the subject of the meeting was the "urgent need to restore order on campus" (B'nai Brith, 2009d). Also addressed was B'nai Brith's objection that all student groups and their leaders involved in the February $12^{\text {th }}$ rally were to be sanctioned, "we object to the moral equivalency reflected in the decision to suspend not just the groups that promote hatred and are the cause of agitation on campus, but also those who have been the targets of such 
aggression." Later that day York President Mamdouh Shoukri addressed York's Senate on the "future of the University," where he stressed that an urgent task for the University was to "fix the way we relate to each other ... We must replace the tension and negativity with reasoned dialogue, so that we can talk to each other and to the wider world" (Shoukri, 2009).

On February $27^{\text {th }}$, United Jewish Appeal (UJA) Federation of Greater Toronto posted an "Update on York University Crisis."

The UJA Federation of Greater Toronto is supporting Hillel and other Jewish student organizations to change the inaction of the York University administration in the wake of a dangerous incident on February 11. Here's what we are specifically seeking:

- University disciplinary measures against those who participated in the February 11 mob behaviour. The university should waive a requirement that affected students must first file a formal complaint. York is significantly behind in processing complaints and has video evidence available of what occurred on February 11.

- Acknowledgement by President Shoukri of the gravity of the threats made specifically against Jewish students.

- Announcement of new measures to ensure the safety and security of Jewish students and others on campus. (Canada-Israel Committee, 2009)

Community members were invited to contact named York officials.

On March $16^{\text {th }}$, the president appointed a Task Force on Student Life, Learning \& Community saying that

We are committed to ensuring that our students can pursue their studies free of harassment or intimidation. . . . This task force will take a hard look at the current environment on campus, and explore ways that we can promote open debate and the free exchange of ideas. (Yfile, 2009b)

The task force was composed of students and faculty appointed, rather oddly, from outside the representative union and student bodies.

Later that spring, the student organization Hillel of Greater Toronto, and Hasbara at York, whose website describes it as "a grassroots, independent organization," (Hasbara, 2011) with support from the UJA Federation of Greater Toronto and the Canadian Council for Israel and Jewish Advocacy, set up a commission to "identify trends affecting the quality of life for Jewish students at York" (Valiante, 2009), which made a submission to the York Task Force on Student Life, Learning \& Community. At the same time B'nai Brith Canada maintained the pressure through ads and columns in the National Post, including a full page ad on June 13, titled, "YORK UNIVERSITY REPORT CARD" — which gave a failing grade for: "ensuring a welcoming and secure environment for all students, providing balanced intellectual academic debate, preventing anti-Israel agitators from spewing hatred," and "ensuring Jewish students are not marginalized and intimidated" (B'nai Brith, 2009e). 
The Presidential Task Force on Student Life, Learning \& Community submitted its final report in August 2009 (Task Force on Student Life, 2009). While placing a welcome emphasis on the importance of freedom of expression, the report was much more concerned with achieving an environment free of intolerance, harassment and intimidation. The Report argues that while providing more avenues for expression should be a goal, unauthorized speech must be constrained by policies incorporating sanctions, including a "student code of conduct" and a "temporary use of university space" policy, regulating and requiring permits to use virtually all public meeting places on the campus. The Report said little about the effect on academic freedom of the relentless media campaign on freedom of expression, designed to mobilize public sentiment on Israeli-Palestinian conflict. But public pressure of the kind just described is in itself an attempt to constrain speech by narrowing the boundaries of what is acceptable.

The Task Force (Task Force on Student Life, 2009) called for "civility, balance and respect" without ever addressing the substance of the debate itself, as if debate can be extracted from its immediate political context. While no one can argue with the Report's anodyne call for "reasoned discussion," it ignores the subjective nature of civility and disrespect. Just consider the debate over the application of the term "apartheid" to Israeli policy towards Palestinians. The difficulty begins with the problematic idea of regulating incivility or disrespect by banning certain forms of speech and sanctioning the guilty parties, but then slides into still murkier waters in attempting to distinguish forceful debate from a noisy and disrespectful demonstration. It is not hard to argue that the harm of disallowing free expression outweighs the good achieved through bans on expression and public speech. After all, it is not true that "a war of words is still a war"- - a slogan heard in a recent York campaign.

In his review of Section 13 of the Canadian Human Rights Act and the regulation of hate speech on the internet, Richard Moon (2008) argues that "ideas cannot be censured simply because we fear that members of the community may find them persuasive or that individuals' self-understanding or self-esteem may be negatively affected" (p. 24). Regarding the regulation of offensive speech more generally, he argues that while "expression that stereotypes or defames the members of an identifiable group is offensive, insulting and harmful to the group's members, nevertheless censorship of this expression is not a viable option" (Moon, 2008, p. 27).

For some time, civility, balance and respect have been the watchwords of US neoconservatives who see to police academic speech and teaching. In recent years David Horowitz has made a professional career of exposing academics that he defines as leftist and promoting the rights of conservative students to an ideology-free education (Cooke, 2007). Horowitz's Freedom Centre aims to "take back" universities from "tenured radicals" and to "promote academic freedom for students, especially conservative students who are a stigmatized minority on campuses these days" (Freedom Centre, 2010). Students For Academic Freedom (2007), a group founded by Horowitz, has promoted an "Academic Bill of Rights" that would enshrine in law the obligation of faculty to provide balanced viewpoints in university teaching.

Writing about this "Academic Bill of Rights" in 2003, Jesse Walker reminds us that the concept of "balance" was also central to the "fairness doctrine," which at one point governed radio and television communications in the US, requiring that every view was presented alongside its opposition. He concludes that, "In practice, it was a way politicians or interest 
groups could harass stations that aired views they disliked" (Walker, 2009, p. 2). In a similar vein, Judith Butler (2006) argues that calls for balance, democracy, and inclusion lead more directly to surveillance and regulation and abridgement of academic freedom. Although she is speaking of faculty academic freedom it is not much of a leap of logic to see how student codes of conduct are becoming part of the academic regulatory apparatus.

The third set of events at York demonstrates that even "academic dialogue" is not safe from intimidation and pressure. While in the environment just described, the organizers of the Conference Israel/Palestine: Mapping Models of Statehood and Paths to Peace, should have expected that the event would be controversial, they had no reason to expect that the conference would become a test of academic freedom, autonomy from state interference, and the integrity of established collegial and peer review processes.

In November 2008 a group of Queen's University and York University academics applied for a Social Sciences and Humanities Research Council (SSHRC) grant for support of a three-day conference to explore

which state models offer promising paths to resolving the Israeli-Palestinian conflict, respecting the rights to self-determination of both Israelis/Jews and Palestinians. Mindful of the fraught context in which debates relating to Israel/Palestine unfold, the conference aims to open up measured and thoughtful conversations on the range of possible paths out of the current impasse. (Israel/Palestine: Mapping Models of Statehood and Paths to Peace Conference, 2009)

The conference was to be held at York University as one of the events celebrating its fiftieth anniversary.

After peer review, the conference organizers were awarded a grant in January 2009. Of course, SSHRC has regulations for accountability and reporting on conference funds. While minor changes to the program, such as last minute speaker additions or cancellations are included in a post conference report, SSHRC must be notified of more significant changes.

As the date of the conference grew closer, organized political protest by pro-Israel advocates mounted. On May 12, 2009 the Canadian Council for Israel and Jewish Advocacy issued a statement condemning the conference, which seems to have launched a flow of complaints to York. The Canadian Jewish Congress and the Jewish Defense League of Canada joined the protest, calling the conference a "virulent anti-Israel hate fest." B'nai Brith Canada called on its constituency to petition the government, SSHRC, and the two sponsoring universities to withdraw moral and financial support from the conference. Other pro-Israeli groups followed suit (B'nai Brith, 2009f).

The pressure paid off. On June 5, less than three weeks before the conference start, Gary Goodyear, the federal Minister of State for Science and Technology, intervened with SSHRC requesting that the Council "consider conducting a second peer review of the application to determine whether or not the conference still meets SSHRC's criteria for funding of an academic conference" (Goodyear, 2009). This outraged the academic community. Citing the Minister's 
political interference as setting a dangerous precedent, the Canadian Association of University Teachers (CAUT) called for the Minister's resignation (CAUT, 2009a).

The CAUT asked for a meeting between its executive and SSHRC President Chad Gaffield and, when he refused to meet, urged Gaffield not to accede to the Minister's request. The SSHRC capitulated to the government's pressure and demanded that the conference organizers account immediately for any changes to the program. In an open letter to Chad Gaffield, the CAUT executive stated:

In an apparent effort to please the Minister, you chose to disregard SSHRC's Grant Holder's Policy that specifies any changes other than a major change to the theme of the conference are to be provided in the organizer's report of activities submitted at the conclusion of the grant. Instead you demanded the information now so as to comply with the Minister's request. Whether or not you allow the funding to go ahead, your actions have legitimated political intervention that sullies SSHRC's record of commitment to standing behind its peer-reviewed decisions. (CAUT, 2009b)

In the end, SSHRC allowed the conference to go ahead as planned.

Throughout the furor, York President Shoukri was a strong advocate for the conference and he made a strong public statement supporting the academic freedom of scholars to explore the thorny issues of statehood. After the conference, however, he announced an inquiry into its planning and organization to be conducted by retired Supreme Court Justice Frank Iacobucci. This seemed a chilling rebuke to conference organizers and left many worried about a retreat at York from its commitment to academic freedom. The terms of reference for the inquiry were particularly worrying. Rather than addressing the assault on academic freedom and autonomy, they focused almost exclusively on the organizing and execution of conferences "of this type" (Yfile, 2009c).

Justice Iacobucci reported to York in November 2009 (Iacobucci, 2010). Like the earlier report of the York Task Force on Student Life, Learning \& Community, his report shifted the emphasis away from the protection of academic freedom as the pre-eminent value of academic life to a concern with the responsibilities entailed by the exercise of the freedom. His recommendations include a review of policies and procedures relating to academic freedom and the creation of a statement of best practices. Similar to the Task Force report, he finds that underlying policies and procedures on academic freedom are "principles," including safety and security of those on campus; civil discourse, mutual respect, standards of integrity in research and sensitivity to equality issues. He recommended the creation of an "Inter-Group Relations Committee" and development of a handbook on academic freedom.

Iacobucci did not consider the vulnerability of academic freedom in the face of the power of external groups to bring pressure to erode this freedom. Nor, beyond a mild statement, does he find any wrongdoing on the part of government or SSHRC. Instead, his review of the conference raises questions about its balance, civility, and respectful dialogue. 
But the fundamental character of academic freedom is that it does not preclude political commitments, nor require that every view be explored. In contrast to the bland idea of disinterest, the pursuit of academic freedom is a commitment to pursue knowledge and to engage scholars prepared to defend critical inquiry. The CAUT policy on Academic Freedom reads:

Academic freedom does not require neutrality on the part of the individual. Academic freedom makes intellectual discourse, critique and commitment possible. All academic staff must have the right to fulfill their functions without reprisal or repression by the institution, the state, or any other source. (CAUT, 2005)

The events at York University exemplify the pressures on academic freedom, as universities are increasingly organized and managed on market principles (Altbach, 2001; Conlon, 2000; Deem, 1998, 2003; Giroux, 2007, 2009; Gumport, 1997; Thorpe, 2009; Thornton, 2009). The rise of commercialization and privatization, as government funding declines, threaten the traditional role of post-secondary education as a public good. As corporate ideals come to govern post-secondary institutions, the idea that post-secondary education is fundamentally a public good gives way to the idea of competition between institutions, nationally and internationally, and to the view that the university is a means for individuals to invest in human capital in order to increase their earnings. The idea that education is fundamentally an individual, rather than a social, benefit justifies the transfer of the costs of post-secondary education to students and their families. The upshot is that the idea that the role of education is in part to create informed, engaged citizens has given way to a model in which consumer choice should determine what is taught in our universities and colleges.

Corporatism and managerialism in universities are associated with what Gumport (2001) and others see as a "drift of authority upwards" from faculty to professional administrators. In Canada over the past two decades there has been a notable increase in the size and capacity of administrative structures and a corresponding hollowing out of traditional governance structures, particularly university senates. As the corporate influence in institutions increased, the idea that faculty self-governance is inefficient and inadequate gained support from external experts like the 1985 report of The Royal Commission on the Economic Union and Development Prospects for Canada (also known as the Macdonald Commission for its chair, Donald S. Macdonald) as well as from senior administrators (Conlon, 2000). The resulting threat to academic selfgovernance and autonomy has implications in terms of a diminished academic freedom (Altbach, 2001).

As the corporate mentality gains hold, employers put concerns about liability and restraint in front of ideals of freedoms, and they expect academic staff to behave more like their private sector corporate counterparts. Faculty members who speak out face pressure to be one of the team and part of the 'brand.' They become the face of the corporation and their value to the institution is measured in commercial outcomes. These trends produce what Beshara Doumani (2006) argues is a culture of conformity in which academic freedom is a luxury and selfcensorship of the norm.

In tandem with the forces transforming the academic world structurally there is an ominous increase in systematic intimidation. While it is not accidental that all three major 
incidents at York University involved Israel and Palestine, they raise fundamental and broad issues. Following the US lead, groups on the political right and religious groups are increasingly bringing pressure to bear on institutions of higher education and on individual faculties. In an interview with Scott Jaschik (2007), Henry Giroux describes the impact of such campaigns: "underlying recent attacks on the university is an attempt not merely to counter dissent but to destroy it and in so doing to eliminate all of those remaining public spaces, spheres, and institutions that nourish and sustain a culture of questioning so vital to a democratic civil society.'(p. 4) Principled, determined, and explicit resistance to external pressure will allow universities to reclaim an intellectual space free from censorship.

Intimidation may be having an impact. In 2009 student and faculty activists at a number of Canadian universities, held a week of debates, educational sessions, and rallies centered on solidarity with Palestine, under the banner Israeli Apartheid Week. The protests were met with stern rebukes. At Carleton University in Ottawa, for example, posters advertising the week were removed at the administration's order and students received an email from the provost informing them they should become familiar with the University Human Rights Policy and the Student Rights and Responsibilities Policy. These were described as "tools to be used to address inappropriate behaviours including discrimination and harassment. Among other sanctions students can be removed from their studies indefinitely" (Winton, 2009). In contrast, events for 2010 Israeli Apartheid Week on many campuses seemed strangely muted with hard to find locations, few ads, and fewer posters.

Academics in North America have been slow to address the transformation of their institutional and academic lives through corporatism or to the challenges to academic freedom. Altbach (2000) notes, there is almost no public discussion of academic freedom. Nor is there much evidence of scholarly interest in the topic. On the political side, academic freedom is a central concern of national faculty associations, such as the CAUT.

The time is short for scholars to recognize the fragility of academic freedom within a world showing growing intolerance for dissent. Part of this work involves the public defense of academic freedom as a basic necessity of academic life, in and out of the classroom. Public institutions are obligated to defend academic freedom and administrators must be held to this obligation. Constraints on academic freedoms, freedom of expression, and autonomy must be vigorously opposed. Also, there is no avoiding the need to address directly a key wellspring of recent attacks, by following Judith Butler (2003) in repudiating the idea that criticism of Israel is anti-Semitic. 


\section{References}

Altbach, P. (2001). Academic freedom: International realities and challenges. Higher Education, 41, pp. 205-219.

Arthurs, H. W. (1995, October). Academic freedom when and where. Notes from a panel discussion, annual conference of the Association of Universities and Colleges in Canada (AUCC), Halifax.

B'nai Brith. (2009a, February 17). Retrieved from http://www.bnaibrith.ca/files/20090217.pdf.

B'nai Brith. (2009b, February 23). Retrieved from http://www.b'naibrith.ca/files/20090223.pdf.

B'nai Brith. (2009c, February 24). Retrieved from http://www.bnaibrith.ca/prdisplay.php?id=1458.

B'nai Brith. (2009d, February 26). Retrieved from http://www.bnaibrith.ca/prdisplay.php?id=1456.

B'nai Brith. (2009e, February 26). Retrieved from http:/www.bnaibrith.ca.

B'nai Brith. (2009f, February 26). Retrieved from http://www.bnaibrith.ca/prdisplay.php?id=1500.

Brand, L. (2007). Middle East studies and academic freedom: Challenges at home and abroad. International Studies Perspectives. 8, pp. 384-395.

Butler, J. (2006). Israel Palestine and the paradoxes of academic freedom. Radical Philosophy, 135, pp. 8-17.

Butler, J. (2003, August 21). No, it's not anti-Semitic. London Review of Books, pp. 19-21. Retrieved from http://www.lrb.co.uk/v25/n16/judith-butler/no-its-not-anti-semitic.

Canada-Israel Committee. (2009, February 27). UJA Federation of Greater Toronto update on York University crisis. Retrieved from http://www.cicweb.ca/scene/2009/02/ujafederation-of-greater-toronto-update-on-york-university-crisis/

CAUT(2009a). CAUT News Release. CAUT calls for Minister Goodyear's resignation over political interference and attack on academic freedom. Retrieved from

http://www.caut.ca/news_details.asp?nid=1334\&page=490

CAUT. (2009b). Letter to Chad Gatfield. Retrieved from http://www.caut.ca/news_details.asp?nid=1336\&page=490.

CAUT. (2005). Policy statement on academic freedom. Retrieved from http://caut.ca/pages.asp?page $=247 \&$ lang $=1$.

Cole, J. (2005). Academic freedom under fire. Daedalus, 134(2), pp. 5-17.

Conlan, M. (2000). Betrayal of the public trust: Corporate governance of Canadian universities. In J. Turk (Ed.), The corporate campus: Commercialization and the dangers to Canada's colleges and universities. Toronto: James Lorimer and Company.

Cooke, M. (2007). Academic freedom: The "danger" of critical thinking. International Studies Perspectives, 8, pp. 396-400.

Doumani, B. (2006). Between coercion and privatization: Academic freedom in the twenty-first century. In B. Doumani (Ed.), Academic freedom after September 11. New York: Zone Books.

Deem, R. (2003). Managing contemporary UK universities-manager-academics and new managerialism. Academic Leadership. The Online Journal 1(3).

Deem, R. (1998). New 'managerialism' and higher education: The management of performances and cultures in universities in the United Kingdom. International Studies in the Sociology of Education, 8(1), pp. 47-70. 
Falk, R. (2007). Academic freedom under seige. International Studies Perspectives, 8, pp. 369375.

Freedom Centre. (2011). Our mission. Retrieved from http://www.horowitzfreedomcenter.org/

Goodfellow, R. (2007, September 26). Arbitration Award. Retrieved from http://www.yufa.org/Grievances/acdemicfreedomNoble/DavidNobleAward.pdf

Goodyear, G. (2009, June). Press release. Ottawa: Office of Gary Goodyear.

Giroux, H. (2009, March). Academic labor in dark times. Retrieved from http://www.counterpunch.org/giroux03112009.html.

Giroux, H. (2009). Democracy's nemesis: The rise of the corporate university. Cultural Studies $\Leftrightarrow$ Critical Methodologies, 9(5), pp. 669-695.

Grainger, B. (2008). York's Middle-East war. Retrieved from http://www.torontolife.com/features/yorks-middle-east-war/?pageno=1.

Gumport, P. (1997). Public universities as academic workplaces. Daedalus, 126(4), pp. 113 136.

Hasbara. (2011). Retrieved from http://hasbara.ca/.

Iacobucci, F. (2010, March). The mapping conference and academic freedom: A report to President Mamdouh Shoukri from the Honourable Frank Iacobucci. Retrieved from http://www.yorku.ca/acreview/iacobucci_report.pdf.

Israel/Palestine: Mapping models of statehood and paths to peace. (2009). Conference June 2224, York University. Retrieved from http://www.yorku.ca/ipconf/index.html.

Jaschik. S. (2007, August). The university in chains. Retrieved from http://dissident voice.org/2007/08/the-university-in-chains/.

Moon, R. (2008). Report to the Canadian Human Rights Commission concerning section 13 of the CHRA and the regulation of hate speech on the Internet. Retrieved from http://www.chrc-ccdp.ca/pdf/moon_report_en.pdf.

Shoukri, M. (2009, February 26). President Shoukri's address to senate. Retrieved from http://www.yorku.ca/mediar/archive/Release.php?Release=1623.

Students for Academic Freedom. (2007). Academic Bill of Rights. Retrieved from http://www.studentsforacademicfreedom.org/documnets/1925/1bor.html.

Task Force on Student Life. (August, 2009) Rights and responsibilities within the university: Report of the presidential task force on student life, learning and community. Retrieved from http://www.yorku.ca/vpstdnts/initiatives/taskforce/report/TaskForce_FINALREPORT.pd f

Thornton, M. (2009). Universities upside down: The impact of the new knowledge economy. Canadian Journal Women and the Law, 21(2), pp. 375-393.

Thorpe, C.( 2008). Captalism, audit, and the demise of the humanistic academy. Workplace, 15, pp. $1-22$.

Valiante, G. (2009, June 17). Jewish groups call for changes at York University: Anti Israeli sentiment; recent incidents at school have left many shocked and shaken. National Post. Retrieved from http://www.normanfinkelstein.com/jewish-groups-urge-those-displaying-palestine-flagsto-be-deported-to-saskatchewan/.

Walker, J. (2003, September 17). Chilling effects: David Horowitz tries to redefine "academic freedom”. Retrieved from http://reason.com/archives/2003/09/17/chilling-effects. 
Winton, E. (2009, February 18). Israeli Apartheid Week under threat by Carleton administration? Retrieved from http://terroroncampus.wordpress.com/category/campus-battlegrounds/.

YFile. (2009a, February 17). York in the media. Retrieved from http://www.yorku.ca/yfile/archive/index.asp?Article=12036.

YFile. (2009b, March 16). President appoints task force to address student environment. Retrieved from http://www.yorku.ca/yfile/archive/index.asp?Article=12233.

Yfile. (2009c, July 31). President Shoukri announces an independent review of academic conference. Retrieved from http://www.yorku.ca/yfile/archive/index.asp?Article=13025.

York University Faculty Association. ( 2007, November 20). Academic Freedom/David Noble Grievance. Retrieved from http://yufa.org/Grievance/academicfreedomNoble/index.html

York University Faculty Association (2005, November 30). Interim decision. Retrieved from http://yufa.org/Grievances/academicfreedomNoble/DavidNoble21_30Nov05.pdf 